\title{
Rewards: A predictor of well-being and service quality of school principals in the North-West province
}

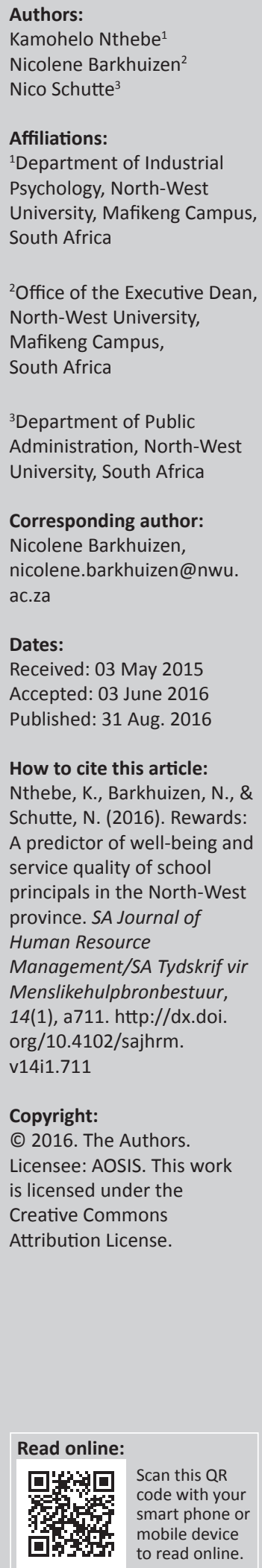

Orientation: School principals have an important role to play in the quality of service delivery in schools. Evidence suggests that school principals are generally poorly compensated, which has an adverse impact on their well-being and subsequent service quality orientation.

Research purpose: This study investigated whether rewards are a predictor of well-being and service orientation of school principals in the North-West province.

Motivation for the study: Effective school principals are fundamental to the success of any school, which necessitates the establishment of an effective reward and remuneration system.

Research design, approach and method: Quantitative research was carried out among school principals $(N=155)$ in four districts of the North-West province. The Total Rewards Scale, Maslach's Burnout Inventory - General Survey, the Utrecht Work Engagement Scale and the SERVQUAL measure were administered among the principals.

Main findings: The results showed that rewards are a significant predictor of the well-being and service quality of school principals. The results further showed that burnout significantly reduces the service quality of school principals. No significant relationships were found between work engagement and the service quality of school principals.

Practical/managerial implications: An effective total rewards system enhances the well-being of school principals and, subsequently, their willingness and commitment to delivering quality services.

Contribution: The results of this study point out some key elements that need to be considered by the Department of Education to enable quality service delivery in South African schools.

\section{Introduction}

The South African school system continues to be under intense scrutiny, criticised for failing to deliver the required services (Department of Basic Education, 2015; South African Human Rights Commission, 2014; Taylor, Mabogoane \& Akoobhai, 2011). Van der Berg, Taylor, Gustafsson, Spaull and Armstrong (2011) found that some of the shortcomings in school teaching practices are attributable to school leadership. The role of school principals in the quality of education in schools is therefore imperative (Ayeni, 2012; Clark, Martorell \& Rockoff, 2009; Steyn, 2013; Trisno \& Nurdianto, 2014).

The demanding role of school principals in maintaining quality education is well documented (Frederici \& Skaalvik, 2011; Newton, 2015; Özer, 2013; Tanjung, 2015). School principals have, among others, the task of managing pupils, handling criticism from parents, and placating frustrated teachers (Boyland, 2011), while at the same time managing daily operations at a school and monitoring the school's infrastructure (plants) (Amanchukwu \& Ololube, 2015). Furthermore, in the midst of the economic downturn and political upheaval, school principals are expected to play an important role in education reform (Bas \& Yildirim, 2012). Therefore, school principals are expected to display the principles of effective and productive leadership, and to make a meaningful contribution to society (Bartlett, 2011; Boyland, 2011).

The South African education system may soon face the dilemma of a 'brain drain' of school principals if they are not managed and compensated well (Maforah \& Schulze, 2012; Reddy et al., 2010; Steyn, 2013). Evidence suggests that the reward system of the Department of Education is not attracting more capable and talented principals (Arends, 2007; Armstrong, 2009; South African Council for Educators, 2010). A study by Maforah and Schulze (2012) showed that poor salaries discourage talented teachers to apply for promotion to the position of school principal. 
This problem is further exacerbated by the fact that remuneration of principals differs in terms of the Post Provision Model (PPM) of the school. According to this model, a school principal of a large school in terms of learners receives a higher salary than the principal of a smaller school (Smit \& Oosthuizen, 2011). The model does not take into consideration the responsibilities or the work load of individual principals (Maarman, Steyn \& Wolhuter, 2006). In large schools, the principal is responsible for management and administration only, and has the support of a complementary school management team, whereas, in small and medium schools, the principal manages and teaches at the same time, and has very few management team members.

School principals therefore have the difficult task of managing a school or classroom successfully, maintaining a healthy family life and preserving their own wellness (Bas \& Yildirim, 2012). Increasing role demands without supportive measures can lead to stress and burnout among school principals (Boyland, 2011). Bakker, Gierveld and van Rijswijk (2006) found that social support from colleagues, together with rewards in the form of career development opportunities, enhances the work engagement (the presumed antidote to burnout) of school principals. Furthermore, a principal's health and well-being, in turn, have an impact on effective and quality service delivery in schools (Igwebuike, 2013).

Against this background, the main objective of this research was to determine whether rewards are a significant predictor of well-being (burnout versus work engagement) and service quality of school principals in the North-West province. Price (2009) postulated that the manner in which people are rewarded affects the quality of their work, their attitude towards customers and their willingness to be flexible or learn new skills and suggest innovations. Moreover, Andreyko (2010) pointed out that the demanding nature of the position of principal results in a shrinking pool of available school leaders. Eventually, teachers and school principals will look outside the Department of Education and beyond the borders of the country for better remuneration (Steyn, 2013). This will leave a vacuum that is very difficult to fill, and will hamper effective service delivery in schools, as envisaged in the Action Plan 2019 Towards the Realisation of Schooling (Department of Basic Education, 2011).

The next section of this article highlights the available literature on the relationships between rewards, well-being and service quality. Flowing from literature review the research method and results are presented, followed by a discussion of the results. This article concludes with recommendations for practice and further research.

\section{Literature review}

\section{Rewards}

Rewards encompass all forms of financial returns and tangible services and benefits employees receive as part of an employment relationship (Milkovich, Newman \& Gerhart, 2013). These include base pay, merit pay, short- and long- term incentives, perquisites, recognition awards, and retention awards (Van der Westhuizen \& Wessels, 2011). For purposes of the present research, the term rewards represents a multidimensional construct consisting of basic salary, benefits, work-life balance, performance management and recognition, and training and development (World at Work Society, 2011). According to the Total Rewards model, compensation includes fixed or variable pay for services rendered. Benefits can include a variety of programmes, such as healthcare and retirement, to provide security for employees and their families. Performance management refers to the alignment between employee efforts and business goals, whereas career development opportunities can assist school principals in advancing their skills and competencies (Bas \& Yildirim, 2012).

According to Chapman (2005), quality principalship cannot be maintained without a coherent, integrated and systematic approach to leadership development. Researchers continue to point out the challenges relating to the career development of school principals. A study by Mulkeen, Chapman, DeJaeghere and Leu (2007) highlighted the need for organised and systematic training to enhance the professionalisation of leadership in education. A study by Bartlett (2011) pointed out the lack of mentoring for school principals, concomitant with poor career development prospects. As regards compensation, a study by Maforah (2010) showed that principals felt that their salaries were not aligned with their workload, and that more effective reward systems were needed. This study furthermore highlighted the poor performance management systems of the Department of Education, as well as policy applications that are eroding the autonomy of principals and their ability to manage effectively.

\section{Well-being}

Well-being is a concept that consists of two opposite poles: burnout and work engagement (Schaufeli, 2003; Schaufeli \& Salanova, 2007). Burnout is a prolonged pathological illbeing condition (Mäkikangas, Kinnunen, Feldt \& Schaufeli, 2016), whereas the concept of work engagement emerged through the positive occupational health psychology movement to denote a positive, fulfilling work-related state of mind (Shimazu \& Schaufeli, 2009). According Bakker and Demerouti (2008), burnout occurs as a result of excessive striving to reach unrealistic work goals, which leads to work overload, patterns of overcommitment, and exhaustion of physical and mental resources (Bakker \& Demerouti, 2008). A person displaying such behaviours for a prolonged period eventually becomes listless, ineffective, inefficient and unproductive (Van der Westhuizen \& Wessels, 2011). Burnout consists of three dimensions, namely exhaustion, mental distance, and lack of professional efficacy (Schaufeli, 2003). Exhaustion refers to a feeling of being overextended and depleted of one's emotional and physical resources (Leiter \& Maslach, 2008). Schaufeli, Taris and Van Rhenen (2008) defined mental distance as a distant attitude towards one's job (cynicism) or people (depersonalisation). Lack of professional efficacy includes feelings of inefficiency, which 
are a result of a tendency to evaluate one's work negatively (Schaufeli \& Taris, 2005).

Burnout is a frequently reported phenomenon in human services professions such as education (Brouwers \& Tomic, 2014; Thomas, Kohli \& Choi, 2014). School principals are particularly prone to emotional and physical burnout, as they have to manage an environment of which humans are the main input and output (Özer, 2013). Continuous intensive interpersonal relationships with problem students, complaining parents, and a criticising society, while having to take care of daily administrative functions, can result in school principals feeling exhausted, aloof, and deprecated (Bas \& Yildirim, 2012; Friedman, 2002). Astudy by Whitehead, Ryba and O'Driscoll (2000) revealed high levels of emotional exhaustion among school principals. Özer (2013) maintained that school principals with a weak sense of efficacy where interpersonal relations are profound are likely to feel physically worn out and experience a sense of despair. According to Tomic and Tomic (2008), school principals who feel a sense of inefficacy may doubt whether they should remain in their job.

Work engagement: According to Scott and McMullen (2010), work engagement includes a high level of employee involvement, commitment to the organisation, and job satisfaction. Work engagement is a positive psychological state of mind and includes three dimensions: vigour, dedication and absorption (Schaufeli \& Bakker, 2010). Vigour is the energy dimension of work engagement and is characterised by high levels of mental resistance and persistence in carrying out difficult tasks (Coetzer \& Rothmann, 2013).

Coetzee and De Villiers (2010) defined dedication as the willingness of people to spend considerable time and effort on doing something meaningful. Absorption is a state in which individuals are fully focused on their work and experience a high level of concentration while performing a task (Bakker, Schaufeli, Leiter \& Taris, 2008).

Work engagement is the all-involved psychological commitment of an employee to the role he or she fulfils in the organisation, and enhances employees' motivation to try harder and invest extra effort (Nel et al., 2008). Work engagement in the context of school education is characterised by a sense of connecting with student learning and identification with the school as employer (Newton, 2015). Engagement of school principals is therefore important, as they are then more willing to take on extra tasks that are not part of their job description, invest more effort in their jobs, share information with other employees, and remain with the organisation longer than employees who are less engaged (Bakker \& Demerouti, 2008; Scott \& McMullen, 2010).

\section{Service quality}

Service quality is an attitude towards the service offered, resulting from a comparison of expectations with perceptions (Cüliberg \& Rosjek, 2010). The service expectations of school principals are varied and extensive. Service quality in the context of student education is the ability of a school to transform students' knowledge base, ability, wisdom and character; to prepare them academically for higher education; and also shape them personally to become responsible and contributing members of society (Al-Refai, Al-Omar, Son \& Hamdy, 2015). School principals further have the responsibility of effectively managing their staff. A study by Dworkin, Saha and Hill (2003) showed that principals who are non-authoritarian, supportive and collegial reduce the incidences of burnout among their staff members, which, in turn, facilitates effective service delivery. Amanchukwu and Ololube (2015) highlighted the importance of school principals managing and monitoring school plants such as buildings, equipment and essential structures for effective teaching and learning.

For purposes of the present research, we used The Five-factor SERVQUAL Model of Parasuraman, Zeithaml and Berry (1988) to assess school principals' service quality orientation. According to this model, service quality consists of five dimensions: Reliability, Responsiveness, Assurance, Empathy, and Tangibles (Sharabi, 2013). Reliability refers to the ability to perform the promised service dependably and accurately. Responsiveness includes the willingness to assist customers and to provide prompt service. Assurance refers to the knowledge and courtesy of employees and their ability to convey trust and confidence. Empathy refers to how a company cares and gives individualised attention to their customers, making the customers feel valued and special. Tangibles refers to the appearance of physical facilities, equipment, personnel and communication materials. Mosahab, Mahamad and Ramayah (2010) found that schools lacked quality service in the areas of responsiveness and tangibles. The importance of school principals in the total quality management of schools cannot be underestimated (Al-Refai et al., 2015; Cheng \& Yau, 2011).

\section{Reciprocity between rewards, well-being, and service quality}

Rewards and burnout: The relationship between rewards and burnout is well documented. According to Leiter and Maslach (2008), insufficient rewards (whether financial, institutional or social) increase people's vulnerability to burnout. This implies that, if a reward is insufficient, it may lead to exhaustion, which will create a callous or excessively detached response to various aspects of the job. A study by Jackson and Rothmann (2006) showed that poor pay and benefits increase incidences of burnout among teachers. Coetzee and De Villiers (2010) further found that burnout in conjunction with poor remuneration result in lower levels of absorption and subsequent lower commitment to an organisation. Tomic and Tomic (2008) alluded to a study of Sari (2004), who found that lack of rewards and recognition, among other factors, is a source of burnout among school principals. Boyland (2011) found that opportunities for professional development and improved performance evaluation processes may reduce incidences of stress and related illnesses among school principals: 
- Hypothesis 1: Rewards would be negatively related to burnout.

Burnout and service quality: The competitive nature of schools, concomitant with increased accountability and responsibilities, is resulting in significant physical and emotional costs for school principals (Andreyko, 2010). Ashtari, Farhady and Khodaee (2009) found that high levels of exhaustion and depersonalisation result in an inability to perform. A study by Abdullah and Yuen (2011) found that high levels of exhaustion result in poor performance among employees in human service organisations. Humborstad, Humborstad and Whitfield (2008) found that burnout reduces a service individual's willingness to deliver quality service. A study by Igwebuike (2013) showed that a principal's health and well-being have a positive influence on educational service delivery. Omanukwue (2013) furthermore found that burnout leads to school principals disengaging from their work tasks, as they find the tasks uninteresting and no longer challenging:

- Hypothesis 2: Burnout would be negatively related to service quality.

Rewards and service quality: According to Armstrong (2012), reward makes a positive impact on performance when it contributes to the development of a high-performance culture. This signifies that, if school principals are rewarded well, their performance will increase, and they will provide a high quality service. According to Sigh (2007), incentives motivate employees to put forth their best efforts, and the average productivity level of labour increases. Reward systems inspire staff to provide their best attempts in performing assigned tasks (Gohari, Kamkar, Hosseinipour \& Zohori, 2013). Demerouti, Bakker and Leiter (2014) found that employees who compensate themselves in terms of career development opportunities are less likely to experience burnout, and are able to perform better on the job. Several studies have shown that both financial and non-financial rewards (i.e. salary, bonus, incentives, allowances and fringe benefits) show a strong relationship with job performance (Ashraf, Bandiera \& Jack, 2014; Osibanjo, Adeniji, Falola \& Heirsmac, 2014). A study by (Billger, 2007) showed that the low pay of school principals was related to poor accountability and, subsequently, poor matric pass rates:

- Hypothesis 3: Rewards would be positively related to service quality.

Rewards and work engagement: Jacobs, Renard and Snelgar (2014) found that intrinsic rewards, such as meaningfulness, choice, competence and progress, resulted in higher levels of work engagement of employees in the South African retail industry. Likewise, Abdelhadi and Drach-Zahavy (2012) found that financial rewards significantly enhance the work engagement of employees. Bakker et al. (2006) found that development opportunities enhance the work engagement of school principals. Bakker et al. (2008) found that performance feedback is the best predictor of work engagement. Bakker, Hakanen, Demerouti and Xhantopoulou (2007) found that job resources, such as appreciation, act as a buffer between pupils' misbehaviour and teachers' work engagement. Effort-reward imbalances can have a negative impact on work engagement (Inoue et al., 2014; Kinnunen, Feldt \& Makikangas, 2008). Therefore, satisfaction with both financial and non-financial rewards is crucial in enhancing the work engagement of employees (Malik, 2013):

- Hypothesis 4: Rewards would be positively related to work engagement.

Work engagement and service quality: According to Newton (2015), organisational science research on employee engagement follows a general trend of exploring human capital as a means for organisations to meet their goals. A study by Salanova et al. (2005) showed that organisational resources and work engagement enhance service climate, which, in turn, has a positive spillover effect on employee performance and customer loyalty. Barkhuizen, Mogwere and Schutte (2014) found that the work engagement of support staff in an academic institution enhances their service quality orientation. In essence, the long-term outcomes of work engagement include better quality products and services and more satisfied and loyal customers (Bakker \& Demerouti, 2008). Koch, Binnewies and Dormann (2015) found that the work engagement of school principals is a motivational catalyst for enhanced innovation and creativity of school teachers. Furthermore, Tanjung (2015) found that the work engagement of school leadership also enhances the professionalism of school teachers:

- Hypothesis 5: Work engagement would be positively related to service quality.

\section{Research design Research approach}

A quantitative, cross-sectional research design was followed in the present study. Cross-sectional research occurs when data are collected from the research participants at a single point in time or during a single, relatively brief time period (Johnson \& Christensen, 2008). Cross-sectional research is ideally suited to testing for correlations between variables (Field, 2009).

\section{Measures}

\section{Sampling}

Public school principals in four districts of the North-West province were identified as the unit of analysis for this study. Of the 300 questionnaires that were distributed, only $155(N=155)$ were received and analysed, which gave a total response of $51.7 \%$. Most of the respondents in this research were female $(65.8 \%)$, aged between 30 and 39 years $(43.2 \%)$, and representative of the black ethnic group (43.2\%). Most of the respondents $(76.1 \%)$ had worked for their current school for more than 16 years, and worked more than 40 hours per week $(67.7 \%)$. 


\section{Measuring instruments}

The Total Rewards Scale (Moore \& Bussin, 2011) was used to measure the rewards practices for school principals. The questionnaire consists of 17 statements that measure five components (i.e. Pay, Benefits, Performance management, Worklife balance and Career development) of the World at Work Model for Total Rewards in Organisations. Responses are measured on a five-point Likert scale ranging from 1 (Not important at all) to 5 (Extremely important). Moore and Bussin (2011) found an overall reliability of 0.821 for the measurement.

The Maslach Burnout Inventory - General Survey (MBI-GS) of Schaufeli, Leiter, Maslach and Jackson (1996) was used to measure the Exhaustion, Cynicism and Professional efficacy dimensions of Burnout. The Depersonalisation dimension of the Maslach Burnout Inventory Educator Survey (MBI-ES) was also included in the questionnaire. Responses to 21 items were given on a six-point scale varying from 0 (Never occurs) to 6 (Occurs every day). The questionnaire was validated in the South African context (Rothmann \& Barkhuizen, 2008), with Cronbach alphas ranging from 0.81 to 0.87 for the three dimensions of Burnout.

The Utrecht Work Engagement Scale (UWES) (Schaufeli \& Bakker, 2003) was used to measure work engagement. The UWES consists of 11 items, and measures three dimensions, namely Vigour, Dedication and Absorption. Responses are provided on a six-point scale varying from 0 (Never occurs) to 6 (Occurs every day). The questionnaire has been validated in the South African context (Barkhuizen \& Rothmann, 2006; Bell \& Barkhuizen, 2011), with Cronbach alphas ranging from 0.78 to 0.85 for the three dimensions of Work engagement.

The researchers adapted the SERVQUAL scale (Parasuraman et al., 1998) to measure five dimensions of the respondents' orientation towards delivering quality service: Reliability, Tangibles, Responsiveness, Assurance and Empathy.

Responses were measured on a six-point Likert scale ranging from 1 (Strongly disagree) to 6 (Strongly agree). The questionnaire has been validated in the South African context (Barkhuizen et al., 2014).

\section{Research procedure}

Permission was obtained from the head of the Department of Education of the North-West province to use the school principals within his jurisdiction as participants. The surveys were distributed in hard copy format to the participants. Ethical clearance was obtained prior to the execution of the study. The confidentiality of the participants was ensured, as the researcher did not request or record the respondents' identity.

\section{Data analysis}

Statistical analysis was carried out using the SPSS program (SPSS Inc., 2015). The reliability and validity of the measuring instruments were determined by means of Cronbach alpha coefficients, as well as exploratory factor analysis. Linear regression analyses were applied to test for the significance of predictive relationships between the variables (see Field, 2009).

\section{Results}

Prior to the testing of the hypotheses, the measurements were subjected to a Kaiser-Meyer-Olkin (KMO) test of sample adequacy and sphericity for factor analyses. The measurements obtained the following KMO measure results: Total Rewards Questionnaire - 0.823, MBI-GS - 0.847, UWES - 0.893 and SERVQUAL - 0.809. The results verified that all the measurements were factorable (Hair, Anderson, Tatham \& Black, 2010). A subsequent confirmatory factor analysis was performed on the four measurements. Confirmatory factors analysis appeared to be the obvious choice, as these measurements have been standardised in the South African context. However, because of poor model fit, the researchers decided to use exploratory factor analysis to uncover the factor structure for the measurements for this sample. Factor analysis was deemed necessary, as it was the first time that these measurements were applied to a sample of school principals in South Africa. The results of the factor analysis are reported next.

\section{Total Rewards Scale}

An exploratory factor analysis, using principal component analysis, was performed on the 17 items of this measurement. The initial analysis showed that four factors could be distinguished, based on the eigenvalues. However, closer inspection of the scree plots showed that three factors could be distinguished. Exploratory factor analysis, using sphericity rotation, was performed, specifying three factors. The factors were labelled Performance management (Factor 1), Benefits (Factor 2) and Career development (Factor 3); these explained $56.772 \%$ of the variance. Five items were deleted because of problematic loadings.

\section{MBI-GS}

An exploratory factor analysis, using the principle component factoring extraction method, was performed on the 21 items of the MBI-GS. The factor analysis resulted in three underlying factors. An exploratory factor analysis, using varimax rotation, was conducted on the MBI-GS, specifying three factors. Two items were deleted because of problematic loadings. The factors were labelled Exhaustion (Factor 1), Professional efficacy (Factor 2) and Mental distance (Factor 3). The three factors explained $50.892 \%$ of the variance.

\section{UWES}

An exploratory factor analysis, using the principle component factoring extraction method, was performed on the 17 items of the UWES. The items of the Absorption scale showed problematic loadings, and were omitted from further analyses. The research therefore only used the Vigour and Dedication scales of the UWES in the analysis. A subsequent factor analysis was done on the 11 items of the 
UWES. The factor analysis resulted in one underlying factor, which was labelled Work engagement. One item was deleted because of a problematic loading. The factor explained $46.312 \%$ of the variance.

\section{SERVQUAL}

An exploratory factor analysis, using the principle component factoring extraction method, was performed on the 22 items of the SERVQUAL measurement. The items of the Tangibles scale showed problematic loadings, and were omitted from further analyses. A subsequent factor analysis was done on the 18 items of the measurement. The factor analysis resulted in three underlying factors, which were labelled Empathy (Factor 1), Assurance (Factor 2) and Responsiveness (Factor 3). The three factors explained $49.893 \%$ of the variance. Two items were deleted because of problematic loadings.

The descriptive statistics of the measurements are reported in Table 1.
The results in Table 1 show acceptable to excellent reliabilities for all the scales of the measurements, except for the Career Development Scale of the Total Rewards Questionnaire (see Field, 2009). This scale was omitted from further analyses. The results showed that, on average, the respondents viewed rewards as important. The results further showed that the respondents showed a low level of professional efficacy and average levels of exhaustion and mental distance. The respondents further indicated average levels of work engagement and a high orientation towards quality service delivery relating to Empathy, Assurance and Responsiveness.

The next section reports the results in terms of the hypotheses. Linear regression analysis was applied to test for predictive relationships between the variables. The results of the interactive relationship between Rewards and Burnout are reported in Table 2.

The results in Table 2 show that Performance management is a significant negative predictor of the Mental distance dimension

TABLE 1: Descriptive statistics of the measurements.

\begin{tabular}{|c|c|c|c|c|c|}
\hline Dimensions & Mean & SD & Skewness & Kurtosis & $\alpha$ \\
\hline Rewards & - & - & - & - & - \\
\hline Performance management & 4.2194 & 0.55853 & -0.386 & 0.364 & 0.806 \\
\hline Benefits & 3.9690 & 0.63210 & -0.454 & 0.128 & 0.721 \\
\hline Career development & 4.4043 & 0.47747 & -0.636 & 0.307 & 0.592 \\
\hline Burnout & - & - & - & - & - \\
\hline Exhaustion & 3.3987 & 1.74155 & -0.251 & -0.898 & 0.857 \\
\hline Mental distance & 3.8849 & 1.02187 & -0.349 & 0.028 & 0.763 \\
\hline Professional efficacy & 2.4363 & 1.27757 & -0.097 & -0.758 & 0.766 \\
\hline Work engagement & 4.1503 & 1.30585 & -0.897 & 0.401 & 0.865 \\
\hline Service orientation & - & - & - & - & - \\
\hline Empathy & 5.5984 & 0.39400 & -0.757 & -0.402 & 0.861 \\
\hline Assurance & 5.5790 & 0.57671 & -0.537 & 0.538 & 0.831 \\
\hline Responsiveness & 5.5774 & 0.45901 & -1.047 & 1.091 & 0.666 \\
\hline
\end{tabular}

TABLE 2: Regression analyses of rewards and burnout.

\begin{tabular}{|c|c|c|c|c|c|c|c|c|}
\hline \multirow[t]{2}{*}{ Model } & \multicolumn{2}{|c|}{ Unstandardised coefficients } & \multirow{2}{*}{$\begin{array}{l}\text { Standardised } \\
\text { coefficients: Beta }\end{array}$} & \multirow[t]{2}{*}{$T$} & \multirow[t]{2}{*}{$P$ (Sig) } & \multirow[t]{2}{*}{$R$} & \multirow[t]{2}{*}{$R^{2}$} & \multirow[t]{2}{*}{$\Delta R^{2}$} \\
\hline & B & SE & & & & & & \\
\hline $\begin{array}{l}\text { Performance management } \\
\text { and exhaustion }\end{array}$ & - & - & - & - & - & 0.146 & 0.021 & 0.015 \\
\hline Constant & 5.314 & 1.061 & - & 5.006 & 0.000 & - & - & - \\
\hline Performance management & -0.454 & 0.249 & -0.146 & -1.820 & 0.071 & - & - & - \\
\hline $\begin{array}{l}\text { Performance management } \\
\text { and professional efficacy }\end{array}$ & - & - & - & - & - & 0.135 & 0.018 & 0.012 \\
\hline Constant & 2.846 & 0.624 & - & 4.563 & 0.000 & - & - & - \\
\hline Performance management & 0.246 & 0.147 & 0.135 & 1.680 & 0.095 & - & - & - \\
\hline $\begin{array}{l}\text { Performance management } \\
\text { and mental distance }\end{array}$ & - & - & - & - & - & 0.172 & 0.029 & 0.023 \\
\hline Constant & 4.093 & 0.775 & - & 5.279 & 0.000 & - & - & - \\
\hline Performance management & -0.393 & 0.182 & -0.172 & -2.155 & $0.033 *$ & - & - & - \\
\hline Benefits and exhaustion & - & - & - & - & - & 0.073 & 0.005 & -0.001 \\
\hline Constant & 4.202 & 0.893 & - & 4.706 & 0.000 & - & - & - \\
\hline Benefits & -0.202 & 0.222 & -0.073 & -0.911 & 0.364 & - & - & - \\
\hline $\begin{array}{l}\text { Benefits and professional } \\
\text { efficacy }\end{array}$ & - & - & - & - & - & 0.235 & 0.055 & 0.049 \\
\hline Constant & 2.379 & 0.511 & - & 4.659 & 0.000 & - & - & - \\
\hline Benefits & 0.379 & 0.127 & 0.235 & 2.987 & $0.003 *$ & - & - & - \\
\hline $\begin{array}{l}\text { Benefits and mental } \\
\text { distance }\end{array}$ & - & - & - & - & - & 0.047 & 0.002 & -0.004 \\
\hline Constant & 2.063 & 0.656 & - & 3.144 & 0.002 & - & - & - \\
\hline Benefits & 0.094 & 0.163 & 0.047 & 0.577 & 0.565 & - & - & - \\
\hline
\end{tabular}

*, Statistically significant. 
of Burnout: $F(1155)=4.646$ and accounted for approximately $17.2 \%$ of the variance of Mental distance $\left(R^{2}=0.029\right.$, adjusted $\left.R^{2}=0.023\right)$. The effect was small. Benefits is a significant positive predictor of Professional efficacy: $F(1155)=8.920$ and accounted for approximately $23.5 \%$ of the variance of Professional efficacy $\left(R^{2}=0.055\right.$, adjusted $\left.R^{2}=0.049\right)$. The effect was small.

Based on the above results, Hypothesis 1, that there is a significant negative relationship between rewards and burnout, is partially accepted. The results of the regression analysis of the relationship between Burnout and Service quality are reported in Table 3.

The results in Table 3 show that Professional efficacy is a significant positive predictor of the Reliability dimension of Service orientation: $F(1154)=5.015$ and accounted for approximately $17.8 \%$ of the variance of Reliability $\left(R^{2}=0.032\right.$, adjusted $\left.R^{2}=0.025\right)$. The effect was small. The results furthermore showed that Mental distance is a significant positive predictor of the Assurance dimension of Service orientation, and accounted for approximately $16.8 \%$ of the variance of Reliability $\left(R^{2}=0.028\right.$, adjusted $\left.R^{2}=0.022\right)$. The effect was small.

Based on the above results, Hypothesis 2, that there is a significant negative relationship between burnout and service quality orientation, is partially accepted. The results of the regression analysis of the relationship between Rewards and Service quality orientation are reported in Table 4.

The results in Table 4 show that Performance management is a significant positive predictor of the Reliability dimension of Service orientation: $F(1154)=7.402$ and accounted for approximately $21.5 \%$ of the variance of Reliability $\left(R^{2}=0.046\right.$, adjusted $\left.R^{2}=0.040\right)$. The effect was small. The results furthermore showed that Benefits is a significant positive predictor of the Assurance dimension of Service orientation, and accounted for approximately $18.8 \%$ of the variance of Reliability $\left(R^{2}=0.035\right.$, adjusted $\left.R^{2}=0.029\right)$. The effect was small. Based on the above results, Hypothesis 3, that rewards are significantly positively related to service quality, is partially accepted. The results of the regression analysis of the relationship between Rewards and Work engagement are reported in Table 5.

The results in Table 5 show that Performance management is a significant positive predictor of Work engagement: $F(1154)=$ 3.925 and accounted for approximately $15.8 \%$ of the variance of Mental distance $\left(R^{2}=0.025\right.$, adjusted $\left.R^{2}=0.019\right)$. The effect was small. Based on the above results, Hypothesis 4, that rewards are significant positively related to the work engagement, is partially accepted. The results of the regression analysis of the relationship between Work engagement and Service quality orientation are reported in Table 6.

The results in Table 6 show no significant relationship between Work engagement and Service quality. Based on the above results, hypothesis 5, that work engagement is positively related to service quality is rejected.

\section{Discussion}

The main objective of this research was to determine whether rewards are a significant predictor of well-being (i.e. burnout versus work engagement) and service quality of school principals. We hypothesised that the availability of rewards enhances the well-being of school principals, which, in turn, has a positive effect on the quality of their service delivery.

TABLE 3: Regression analyses of rewards and service quality orientation.

\begin{tabular}{|c|c|c|c|c|c|c|c|c|}
\hline \multirow[t]{2}{*}{ Model } & \multicolumn{2}{|c|}{ Unstandardised coefficients } & \multirow{2}{*}{$\begin{array}{c}\text { Standardised } \\
\text { coefficients: Beta }\end{array}$} & \multirow[t]{2}{*}{$T$} & \multirow[t]{2}{*}{$P$ (Sig) } & \multirow[t]{2}{*}{$R$} & \multirow[t]{2}{*}{$R^{2}$} & \multirow[t]{2}{*}{$\Delta R^{2}$} \\
\hline & $B$ & SE & & & & & & \\
\hline $\begin{array}{l}\text { Performance management } \\
\text { and reliability }\end{array}$ & - & - & - & - & - & 0.215 & 0.046 & 0.040 \\
\hline Constant & 4.959 & 0.237 & - & 20.920 & 0.000 & - & - & - \\
\hline Performance management & 0.152 & 0.056 & 0.215 & 2.721 & $0.007^{*}$ & - & - & - \\
\hline $\begin{array}{l}\text { Performance management } \\
\text { and assurance }\end{array}$ & - & - & - & - & - & 0.020 & 0.000 & -0.006 \\
\hline Performance management & 0.021 & 0.083 & 0.020 & 0.250 & 0.803 & - & - & - \\
\hline $\begin{array}{l}\text { Performance management } \\
\text { and responsiveness }\end{array}$ & - & - & - & - & - & 0.092 & 0.008 & 0.002 \\
\hline Constant & 5.260 & 0.282 & - & 18.680 & 0.000 & - & - & - \\
\hline Performance management & 0.075 & 0.066 & 0.092 & 1.138 & 0.257 & - & - & - \\
\hline Benefits and reliability & - & - & - & - & - & 0.144 & 0.021 & 0.014 \\
\hline Constant & 5.242 & 0.200 & - & 26.159 & 0.000 & - & - & - \\
\hline Benefits and assurance & - & - & - & - & - & 0.188 & 0.035 & 0.029 \\
\hline Constant & 4.900 & 0.291 & - & 16.829 & 0.000 & - & - & - \\
\hline Benefits & 0.171 & 0.072 & 0.188 & 2.362 & $0.019^{*}$ & - & - & - \\
\hline $\begin{array}{l}\text { Benefits and } \\
\text { responsiveness }\end{array}$ & - & - & - & - & - & 0.100 & 0.010 & 0.004 \\
\hline Constant & 5.289 & 0.235 & - & 22.531 & 0.000 & - & - & - \\
\hline Benefits & 0.073 & 0.058 & 0.100 & 1.244 & 0.215 & - & - & - \\
\hline
\end{tabular}

$*$, Statistically significant. 
TABLE 4: Regression analyses of burnout and service quality orientation.

\begin{tabular}{|c|c|c|c|c|c|c|c|c|}
\hline \multirow[t]{2}{*}{ Model } & \multicolumn{2}{|c|}{ Unstandardised coefficients } & \multirow{2}{*}{$\begin{array}{c}\text { Standardised } \\
\text { coefficients: Beta }\end{array}$} & \multirow[t]{2}{*}{$T$} & \multirow[t]{2}{*}{$P$ (Sig) } & \multirow[t]{2}{*}{$R$} & \multirow[t]{2}{*}{$R^{2}$} & \multirow[t]{2}{*}{$\Delta R^{2}$} \\
\hline & $B$ & SE & & & & & & \\
\hline Exhaustion and reliability & - & - & - & - & - & 0.111 & 0.012 & 0.006 \\
\hline Constant & 5.513 & 0.069 & - & 79.474 & 0.000 & - & - & - \\
\hline Exhaustion & 0.025 & 0.018 & 0.111 & 1.380 & 0.169 & - & - & - \\
\hline Exhaustion and assurance & - & - & - & - & - & 0.144 & 0.021 & 0.014 \\
\hline Constant & 5.417 & 0.101 & - & 53.577 & 0.000 & - & - & - \\
\hline $\begin{array}{l}\text { Exhaustion and } \\
\text { responsiveness }\end{array}$ & - & - & - & - & - & 0.053 & 0.003 & -0.004 \\
\hline Constant & 5.530 & 0.081 & - & 68.103 & 0.000 & - & - & - \\
\hline Exhaustion & 0.014 & 0.021 & 0.053 & 0.651 & 0.516 & - & - & - \\
\hline Efficacy and reliability & - & - & - & - & - & 0.178 & 0.032 & 0.025 \\
\hline Constant & 5.332 & 0.123 & - & 43.280 & 0.000 & - & - & - \\
\hline Efficacy & 0.069 & 0.031 & 0.178 & 2.240 & $0.027^{*}$ & - & - & - \\
\hline Constant & 5.475 & 0.183 & - & 29.909 & 0.000 & - & - & - \\
\hline Efficacy & 0.027 & 0.046 & 0.048 & 0.590 & 0.556 & - & - & - \\
\hline Efficacy and responsiveness & - & - & - & - & - & 0.085 & 0.007 & 0.001 \\
\hline Constant & 5.725 & 0.145 & - & 39.397 & 0.000 & - & - & - \\
\hline Efficacy & -0.038 & 0.036 & -0.085 & -1.052 & 0.295 & - & - & - \\
\hline $\begin{array}{l}\text { Mental distance and } \\
\text { reliability }\end{array}$ & - & - & - & - & - & 0.149 & 0.022 & 0.016 \\
\hline Constant & 5.487 & 0.068 & - & 80.951 & 0.000 & - & - & - \\
\hline Mental distance & 0.046 & 0.025 & 0.149 & 1.859 & 0.065 & - & - & - \\
\hline $\begin{array}{l}\text { Mental distance and } \\
\text { assurance }\end{array}$ & - & - & - & - & - & 0.168 & 0.028 & 0.022 \\
\hline Constant & 5.395 & 0.099 & - & 54.544 & 0.000 & - & - & - \\
\hline Mental distance & 0.076 & 0.036 & 0.168 & 2.104 & $0.037^{*}$ & - & - & - \\
\hline $\begin{array}{l}\text { Mental distance and } \\
\text { responsiveness }\end{array}$ & - & - & - & - & - & 0.142 & 0.020 & 0.014 \\
\hline
\end{tabular}

*, Statistically significant.

TABLE 5: Regression analyses of rewards and work engagement.

\begin{tabular}{|c|c|c|c|c|c|c|c|c|}
\hline \multirow[t]{2}{*}{ Model } & \multicolumn{2}{|c|}{ Unstandardised coefficients } & \multirow{2}{*}{$\begin{array}{c}\text { Standardised } \\
\text { coefficients: Beta }\end{array}$} & \multirow[t]{2}{*}{$T$} & \multirow[t]{2}{*}{$P$ (Sig) } & \multirow[t]{2}{*}{$\boldsymbol{R}$} & \multirow[t]{2}{*}{$R^{2}$} & \multirow[t]{2}{*}{$\Delta R^{2}$} \\
\hline & B & SE & & & & & & \\
\hline $\begin{array}{l}\text { Performance management } \\
\text { and work engagement }\end{array}$ & - & - & - & - & - & 0.158 & 0.025 & 0.019 \\
\hline Constant & 2.590 & 0.794 & - & 3.261 & 0.001 & - & - & - \\
\hline Performance management & 0.370 & 0.187 & 0.158 & 1.981 & $0.049 *$ & - & - & - \\
\hline $\begin{array}{l}\text { Benefits and work } \\
\text { engagement }\end{array}$ & - & - & - & - & - & 0.154 & 0.024 & 0.017 \\
\hline Benefits & 0.317 & 0.165 & 0.154 & 1.922 & 0.056 & - & - & - \\
\hline
\end{tabular}

*, Statistically significant.

TABLE 6: Regression analyses of work engagement and service quality.

\begin{tabular}{|c|c|c|c|c|c|c|c|c|}
\hline \multirow[t]{2}{*}{ Model } & \multicolumn{2}{|c|}{ Unstandardised coefficients } & \multirow{2}{*}{$\begin{array}{c}\text { Standardised } \\
\text { coefficients: Beta }\end{array}$} & \multirow[t]{2}{*}{$T$} & \multirow[t]{2}{*}{$P$ (Sig) } & \multirow[t]{2}{*}{$R$} & \multirow[t]{2}{*}{$R^{2}$} & \multirow[t]{2}{*}{$\Delta R^{2}$} \\
\hline & $B$ & SE & & & & & & \\
\hline $\begin{array}{l}\text { Work engagement and } \\
\text { reliability }\end{array}$ & - & - & - & - & - & 0.060 & 0.004 & -0.003 \\
\hline Constant & 5.523 & 0.106 & - & 52.150 & 0.000 & - & - & - \\
\hline Work engagement & 0.018 & 0.024 & 0.060 & 0.746 & 0.457 & - & - & - \\
\hline $\begin{array}{l}\text { Work engagement and } \\
\text { assurance }\end{array}$ & - & - & - & - & - & 0.112 & 0.012 & 0.006 \\
\hline Work engagement & -0.049 & 0.035 & -0.112 & -1.392 & 0.166 & - & - & - \\
\hline $\begin{array}{l}\text { Work engagement and } \\
\text { responsiveness }\end{array}$ & - & - & - & - & - & 0.041 & 0.002 & -0.005 \\
\hline Constant & 5.637 & 0.124 & - & 45.641 & 0.000 & - & - & - \\
\hline Work engagement & -0.014 & 0.028 & -0.041 & -0.503 & 0.615 & - & - & - \\
\hline
\end{tabular}


The results showed that the availability of performance management systems decreases the mental distance of school principals. In line with the findings of Boyland (2011), these results suggest that adequate performance evaluation systems may reduce incidences of stress-related illnesses such as burnout. As a result, we would expect school principals to display less callous attitudes towards their job and the individuals (i.e. school pupils, teachers and parents) who are the recipients of their service (Schaufeli et al., 2008). The results further show that the availability of benefits enhances the professional efficacy of school principals. A school system that provides adequate benefits will therefore enhance school principals' self-belief that they are capable of performing well in their job (Bas \& Yildirim, 2012).

The results of this study confirmed that professional efficacy enhances reliable service delivery of school principals. School principals who have a strong professional self-belief will therefore be able to manage and maintain school plants and culture, so that services can be delivered in an accurate and timely manner to school pupils and the broader community (Amanchukwu \& Ololube, 2015). The mental distance of school principals in this study was found to be positively related to the Assurance dimension of Service quality. The results can be explained by the fact that the school principals displayed average levels of mental distance, indicating that they are not experiencing a strong detachment from the people that are working with or their work tasks. As a result, these school principals might build effective interpersonal and trusting relationships with teaching staff, school pupils, and parents (Nel et al., 2008), while walking the extra mile to do meaningful work (Scott \& McMullen, 2010).

In line with previous research, the results of this study also showed that the quality of service delivery of school principals is dependent on an effective rewards system (Ashraf et al., 2014; Demerouti et al., 2014). The availability of a performance management and subsequent acknowledgement system will increase the accurate and reliable service delivery of school principals (Billger, 2007). The availability of benefits enhanced the Assurance dimension of Service quality of school principals, which enables them to instil confidence and trust in teachers to deliver quality services through innovation and creativity (Koch et al., 2015). Performance management was also found to be positively related to work engagement. This implies that job resources in the form of performance feedback and appreciation will increase the work engagement of school principals (Bakker et al., 2007, 2008). In contrast with previous research, work engagement was not found to be significantly related to the quality of service of school principals (Bakker \& Demerouti, 2008; Salanova et al., 2005).

\section{Practical implications}

School principals play an important role in the quality service delivery of schools. The results of this study highlighted the importance of an adequate school reward system that includes adequate performance management systems, performance evaluation, and performance feedback. As shown by the results, performance management plays an important role in decreasing job burnout, and enhances work engagement and subsequent service quality. Furthermore, the availability of benefits was found to increase school principals' sense of professional self-efficacy, which, in turn, enhances reliable service delivery and quality. Performance management, in conjunction with benefits, is therefore imperative for the effective functioning of school principals.

\section{Limitations}

The study had some limitations. Firstly, a cross-sectional research design was used, which limited the research in terms of making cause-and-effect inferences over the long term. The study used self-assessment as the method of data collection. This means that the results are based on the perceptions of the participants. Only questionnaires were used to collect the data; other methods such as observation and interviewing could have been used to obtain another perspective.

\section{Recommendations}

This study has implications for future research. Larger studies using longitudinal data representing all the principals in the country are needed to provide additional evidence in support of our main findings. It should be noted that the study findings can be relevant to all levels of management, from line- and middle- to top-management, in various sectors of government. From a methodological point of view, the items of the SERVQUAL measure should be revisited to present an accurate reflection of the five dimensions of Service quality. The analyses of the SERVQUAL measure in this study resulted in various cross-loadings, rendering factors such as Tangibles and Empathy unusable. Furthermore, the items of the Total Rewards Questionnaire should be expanded to give a more accurate reflection of the five dimensions of the Total Rewards Model that formed the foundation of this research.

\section{Conclusion}

In conclusion, schools need effective principals to succeed and deliver quality services. It is vital that the Department of Education look after school principals, to curb the brain drain. Researchers have revealed that many organisations, particularly in the public sector, fail to address the needs of their employees, which causes them to be victims of burnout and eventually quit. It is quite evident that many educators, including principals, quit because of poor remuneration, which has led to a shortage of skilled personnel in schools. It is of paramount importance that schools look closely at the impact of reward on the wellbeing of school principals and their service quality.

\section{Acknowledgements Competing interests}

The authors declare that they have no financial or personal relationships which may have inappropriately influenced them in writing this article. 


\section{Authors' contributions}

This article is based on the Masters research of K.N., of which N.B. and N.S. were the research supervisors. N.B. wrote the article and K.N. and N.S. provided editorial inputs.

\section{References}

Abdelhadi, N., \& Drach-Zahavy, A. (2012). Promoting patient care: Work engagement as a mediator between ward service climate and patient-centred care. Journal of Advanced Nursing, 68, 1276-1287. http://dx.doi.org/10.1111/ j.1365-2648.2011.05834.x

Abdullah, D.N.M.A., \& Yuen, F.C. (2011). The impact of job burnout towards job performance among nurses. In Proceedings of the IEEE Symposium on Business, Engineering and Industrial Applications, Langkawi, Malaysia, pp. 351-356, 25-28 September Institute of Electrical and Electronics Engineers, Piscataway, New Jersey, NJ: United States of America.

Al-Refai, A.I., Al-Omar, H.O., Son, M.S., \& Hamdy, H.I. (2015). Managing service quality of high school delivery: Evidence from Kuwait. International Journal of Education 7, 67-94. http://dx.doi.org/10.5296/ije.v7i2.5803

Amanchukwu, R.N., \& Ololube, N.P. (2015). Managing school plants for effective service delivery in public schools in River State of Nigeria. Human Resource service delivery in public schools in
Management Research, 5, 95-102.

Andreyko, T.A. (2010). Principal leadership in the accountability era: Influence of expanding job responsibilities on functional work performance, stress management, and overall job satisfaction. Unpublished doctoral dissertation, Graduate Faculty of the School of Education, University of Pittsburgh, Pittsburgh, PA: United States of America.

Arends, F. (2007). The employment status of educators. Paper presented at the Teacher Development and Institutional Change in an Evolving Education Context, Johannesburg, South Africa, 28-29 May.

Armstrong, A. (2009). Teacher pay in South Africa: How attractive is the teaching profession? Stellenbosch Economic Working Papers. Stellenbosch University, South Africa.

Armstrong, M. (2012). Armstrong's hand book of human resource managemen practice. (12th edn.). London: Kogan Page.

Ashraf, N., Bandiera, O., \& Jack, B.K. (2014). No margin, no mission? A field experiment on incentives for the public service industry. Journal of Public Economics, 120, 1-17. http://dx.doi.org/10.1016/j.jpubeco.2014.06.014

Ashtari, Z., Farhady, Y., \& Khodaee, M.R. (2009). Relationship between job burnout and work performance in a sample of Iranian mental health staff. African Journal of Psychology, 12, 71-74.

Ayeni, A.J. (2012). Assessment of school principals' supervisory roles for quality assurance in secondary schools in Ondo State, Nigeria. World Journal of Education, 2, 62-69. http://dx.doi.org/10.5430/wje.v2n1p62

Bakker, A.B., \& Demerouti, E. (2008). Towards a model of work engagement. Career Development International, 13, 209-223. http://dx.doi.org/10.1108/1362043081 0870476

Bakker, A.B., Gierveld, J.H., \& Rijkswijk, K. (2006). Successfactoren bij vrouwelijke schoolleiders in het primair onderwijs: Een onderzoek na burnout, bevlogenheid en prestaties [Success factors among female school principals in primary teaching: A study on burnout, work engagement and performance]. Diemen, The Netherlands: Right Management Consultants.

Bakker, A.B., Hakanen, J.J., Demerouti, E., \& Xanthopoulou, D. (2007). Job resources boost work engagement, particularly when job demands are high. Journal of Educational Psychology, 99, 274-284. http://dx.doi.org/10.1037/0022-0663.99.2.274

Bakker, A.B., Schaufeli, W.B., Leiter, M.P., \& Taris T.W. (2008). Work engagement: An emerging concept in occupational psychology. Work \& Stress, 22, 187-200. http:// dx.doi.org/10.1080/02678370802393649

Barkhuizen, E.N., Mogwere, P., \& Schutte, N.E. (2014). Talent management, work engagement and service quality orientation of support staff in a higher education institution. Mediterranean Journal of Social Sciences, 5, 69-77. http://dx.doi. org/10.5901/mjss.2014.v5n4p69

Barkhuizen, E.N., \& Rothmann, S. (2006). Work engagement of academic staff in South African higher education institutions. Management Dynamics, 15, 38-48.

Bartlett, C. (2011). Principal succession: Trends and impacts. Unpublished doctoral thesis, Faculty of College and Education, University of Houston, Austin, Texas: TX, United States of America.

Bas, G., \& Yildirim, A. (2012). An analysis of burnout of Turkish elementary school principals. Journal of Educational and Instructional Studies in the World, 2, 62-73.

Bell, E., \& Barkhuizen, E.N. (2011). The relationship between barriers to change and work engagement of employees in a South African property management company. South African Journal of Industrial Psychology, 37, 1-11. http://dx.doi. org/10.4102/sajip.v37i1.935

Billger, S.M. (2007). Principals as agents? Investigating accountability in the compensation and performance of school principals. Bonn, Germany: Institute for the Study of Labour.

Boyland, L. (2011). Job stress and coping strategies of elementary principals: A statewide study. Current Issues in Education, 14, 1-11.

Brouwers, A., \& Tomic, W. (2014). A longitudinal study of relationships between three burnout dimensions among secondary school teachers. Sensoria: A Journal of Mind, Brain \& Culture, 10, 23-33. http://dx.doi.org/10.7790/sa.v10i2.409
Chapman, J.D. (2005). Recruitment, retention and development of school principals. Brussels, Belgium: International Academy of Education.

Cheng, A.L.F., \& Yau, H.K. (2011). Principals' and teachers' perceptions of quality management in Hong Kong primary schools. Quality Assurance in Education, 19, 170-186. http://dx.doi.org/10.1108/09684881111125069

Clark, D., Martorell, P., \& Rockoff, J. (2009). School principals and school performance. Washington, DC: Calder, The Urban Institute.

Coetzee, M., \& De Villiers, M. (2010). Sources of job stress, work engagement and career orientations of employees in a South African financial institution. South African Business Review, 14, 27-43.

Coetzer, C.F., \& Rothmann, S. (2013). Job demands, job resources and work engagement of employees in a manufacturing organization. South African Business Review, 11, 17-32.

Cüliberg, B., \& Rosjek, I. (2010). Identifying service quality dimensions as antecedents to customer satisfaction in retail banking. Economic \& Business Review, 12, 151-166.

Demerouti, E., Bakker, A.B., \& Leiter, M. (2014). Burnout and job performance: The moderating role of selection, optimisation, and compensation strategies. Journal of Occupational Health Psychology, 19, 96-107. http://dx.doi.org/10.1037/ a0035062

Department of Basic Education. (2011). Action plan to 2014: Towards the realisation of schooling 2025. Pretoria, South Africa: Department of Basic Education.

Department of Basic Education. (2015). Education statistics in South Africa 2013. Pretoria, South Africa: Department of Basic Education.

Dworkin, A.G., Saha, L.J., \& Hill, A.N. (2003). Teacher burnout and perceptions of a democratic school environment. International Education Journal, 4, 108-120.

Field, A. (2009). Discovering statistics using SPSS. (3rd edn.). London: Sage Publications.

Frederici, R.A., \& Skaalvik, E.M. (2011). Principal self-efficacy and work engagement: Assessing a Norwegian Principal Self-Efficacy Scale. Social Psychology Education, 14, 575-600. http://dx.doi.org/10.1007/s11218-011-9160-4

Friedman, I.A. (2002). Burnout in school principals: Role related antecedents. Social PsychologyofEducation, 5,229-251. http://dx.doi.org/10.1023/A:1016321210858

Gohari, P., Kamkar, A., Hosseinipour, S.J., \& Zohori, M. (2013). Relationship between rewards and employee performance: A mediating role of job satisfaction. Interdisciplinary Journal of Contemporary Research in Business, 5, 571-597.

Hair, J.F., Black, W.C., Babin, B.J., \& Anderson, R.E. (2010). Multivariate data analysis: A global perspective. (7th edn.). Upper Saddle River, NJ: Pearson Education.

Humborstad, S.I.W., Humborstad, B., \& Whitfield, R. (2008). Burnout and service employees' willingness to deliver quality service. Journal of Human Resources in Hospitality and Tourism, 7, 45-64. http://dx.doi.org/10.1300/J171v07n01_03

Igwebuike, F.K. (2013). The school principals' health and wellness status for quality education service delivery in Enugu State. Mediterranean Journal of Socia Sciences, 4, 67-73. http://dx.doi.org/10.5901/mjss.2013.v4n12p67

Inoue, A., Kawakami, N., Tsutsumi, A., Shimazu, A., Miyaki, K., Takahashi, M., et al., (2014). Association of job demands with work engagement of Japanese (2014). Association of job demands with work engagement of Japar
employees: Comparison of challenges with hindrances. PLoS One, 9, 1-8.

Jackson, L., \& Rothmann, S. (2006). Occupational stress, organizational commitment and ill health of educators in the North-West province. South African Journal of Education, 26, 75-95.

Jacobs, S., Renard, M., \& Snelgar, R.J. (2014). Intrinsic rewards and work engagement in the South African retail industry. SA Journal of Industrial Psychology, 40, 1-13. http://dx.doi.org/10.4102/sajip.v40i2.1195

Johnson, L.T.B., \& Christensen, L. (2008). Educational research: Quantitative \& qualitative and mixed approaches. (3rd edn.). London: Sage Publications.

Kinnunen, U., Feldt, T., \& Makikangas, A. (2008). Testing the effort-reward imbalance model among Finish managers: The role of perceived organizational support.
Journal of Occupational Health Psychology, 13, 114-127. http://dx.doi. Journal of Occupational Health
org/10.1037/1076-8998.13.2.114

Koch, A.R., Binnewies, C., \& Dormann, C. (2015). Motivating innovation at schools: School principals' work engagement as a motivator for school's innovation.
European Journal of Work and Organisational Psychology, 24, 505-517. http:// European Journal of Work and Organisation
dx.doi.org/10.1080/1359432X.2014.958471

Leiter, M.P., \& Maslach, C. (2008). Early predictors of job burnout and engagement. Journal of Applied Psychology, 93, 493-512.

Maarman, R., Steyn, E., \& Wolhuter, C. (2006). Optimal demographic information for policy development in the South African education system. South African Journa of Education, 16, 295-304.

Maforah, T.P. (2010). The job satisfaction of principals of previously disadvantaged schools in the North-West province. Unpublished doctoral thesis, School of Education, University of South Africa, Pretoria, South Africa.

Maforah, T.P., \& Schulze, S. (2012). The job satisfaction of principals of previously disadvantaged schools: New light on an old issue. South African Journal of disadvantaged schools:
Education, 32, 227-239.

Mäkikangas, A., Kinnunen, U., Feldt, T., \& Schaufeli, W.B. (2016). The longitudinal development of employee well-being: A systematic review. Work \& Stress, 31 331-345. http://dx.doi.org/10.1080/02678373.2015.1126870

Malik, T. (2013). Positive effects of opinion-count on job satisfaction of team members in business enterprises. Journal of Communication Management, 17, 56-74. http://dx.doi.org/10.1108/13632541311300151

Milkovich, G.T., Newman, J.M., \& Gerhart, B. (2013). Compensation. (11th edn.). New York: McGraw-Hill International Edition.

Moore, A., \& Bussin, M. (2011). Reward preferences for generations in selected information and communication technology companies. SA Journal of Human Resource Management, 10, 1-9. 
Mosahab, R., Mahamad, T., \& Ramayah, R. (2010). Service quality, customer satisfaction and loyalty: A test of mediation. International Business Research, 3, 72-80. http://dx.doi.org/10.5539/ibr.v3n4p72

Mulkeen, A., Chapman, D.W., DeJaeghere, J.G., \& Leu, E. (2007). Recruiting, retaining, and retraining secondary school teachers and principals in Sub-Saharan Africa. Washington, DC: African Region Human Development Department, The World Bank.

Nel, P.S., Werner, A., Haasbroek, G.D., Poisat, P., Sono, T., \& Schulz, H.B. (2008). Human resource management. (7th edn.). Cape Town: Oxford University Press.

Newton, P. (2015). Employee engagement in Saskatchewan school divisions: Literature review, conceptualisation and policy analyses. College of Education, University of Saskatchewan, Saskatoon, SK: Canada.

Omanukwue, P.N. (2013). Factors that influence job engagement among heads of departments at secondary schools in Eldorado Park. Unpublished master's dissertation, Department of Management, University of Johannesburg, Johannesburg, South Africa.

Osibanjo, O.A., Adeniji, A.A., Falola, H., \& Heirsmac, P.T. (2014). Compensation packages: A strategic tool for employee's performance and retention. Leonardo Journal of Social Sciences, 25, 65-84.

Özer, N. (2013). Investigation of primary school principals' sense of self-efficacy and burnout. Middle-East Journal of Scientific Research, 15, 682-691.

Parasuraman, A., Zeithaml, V.A., \& Berry, L.L. (1988). SERVQUAL: A multi-item scale for measuring customer perceptions of service quality. Journal of Retailing, 64, 12-42.

Price, J.K. (2009). The role of tenure as a moderator to work engagement and job satisfaction. Unpublished master's dissertation, San Jose State University, Washington, San Jose: CA: United Stated of America.

Reddy, V., Prinsloo, C.H., Netshitangani, T., Moletsane, R., Juan, A., \& van Rensburg, D.J. (2010). An investigation into educator leave in the South African ordinary public schooling system. Commissioned by Unicef for the Department of public schooling system. Commiss

Rothmann, S., \& Barkhuizen, N. (2008). Burnout of academic staff in South African higher education institutions. South African Journal of Higher Education, 22(2), 439-456. http://dx.doi.org/10.4314/sajhe.v22i2.25796

Salanova, M., Llorens, S., Garcia, M., Bürriel, R., Bresó, E., \& Schaufeli, W.B. (2005) Towards a four-dimensional model of burnout: A multi-group factor-analytic study
including depersonalisation and cynicism. Educational and Psychological Measurement, 65, 901-913. http://dx.doi.org/10.1177/0013164405275662

Sari, H. (2004). An analysis of burnout and job satisfaction among Turkish special school head teachers and teachers, and the factors affecting their burnout and job satisfaction. Educational Studies, 30, 291-306. http://dx.doi.org/10.1080/0305 s69042000224233

Schaufeli, W.B. (2003). Past performance and future perspectives of burnout research SA Journal of Industrial Psychology, 29, 1-15. http://dx.doi.org/10.4102/sajip. V29i4.127

Schaufeli, W.B., \& Bakker, A.B. (2003). UWES - Utrecht Work Engagement Scale: Test manual. Utrecht, The Netherlands: Department of Psychology, Utrecht University.

Schaufeli, W.B., \& Bakker, A.B. (2010). Defining and measuring work engagement: Bringing clarity to the concept. In A.B. Bakker \& M.P. Leiter (Eds.), Work engagement: $A$ handbook of essential theory and research (pp. 10-24). New York: Psychology Press.

Schaufeli, W.B., Leiter, M.P., Maslach, C., \& Jackson, S.E. (1996). Maslach burnout inventory - General survey. In C. Maslach, S.E. Jackson, \& M.P. Leiter (Eds.), The Maslach burnout inventory - Test manual. (3rd edn. pp. 19-26). Palo Alto, CA Consulting Psychologists Press.

Schaufeli, W.B., \& Salanova, M. (2007). Efficacy or inefficacy, that's the question: Burnout and work engagement, and their relationships with efficacy beliefs. Anxiety, Stress \& Coping, 20, 177-196. http://dx.doi.org/10.1080/10615800701217878
Schaufeli, W.B., \& Taris, T.W. (2005). Commentary. The conceptualisation and measurement of burnout: Common grounds and work apart. Work \& Stress, 19 measurem 362 .

Schaufeli, W.B., Taris, T.W., \& Van Rhenen, W. (2008). Workaholism, burnout, and work engagement: Three of a kind or three different kinds of employee well-being? Applied Psychology: An International Review, 75, 173-203. http://dx.doi. org/10.1111/j.1464-0597.2007.00285.x

Scott, D., \& McMullen, T. (2010). The impact of rewards program on employee engagement. Scottsdale, AZ: WorldatWork - The Total Rewards Association.

Sharabi, M. (2013). Managing and improving service quality in higher education. International Journal of Quality and Service Sciences, 5, 309-320. http://dx.doi. org/10.1108/IJQSS-03-2013-0016

Shimazu, A., \& Schaufeli, W.B. (2009). Towards a positive occupational health psychology: The case of work engagement. Japanese Journal of Stress Science, 24, 181-187.

Sigh, B.D. (2007). Compensation and reward management. New Delhi, Excel Books.

Smit, M.H., \& Oosthuizen, I.J. (2011). Improving school governance through participative democracy and the law. South African Journal of Education, 31, 55-73.

South African Council for Educators. (2010). A review of teacher demand and supply: Identifying research gaps and the role of SACE. Pretoria: South African Council for Educators.

South African Human Rights Commission. (2014). Report: Delivery of primary learning materials to schools. South African Human Rights Commission, Braamfontein, Johannesburg.

SPSS Inc. (2015). SPSS 23 for windows. Chicago, IL: SPSS Inc.

Steyn, T. (2013). Professional and organisational socialisation during leadership succession of a school principal: A narrative inquiry using visual ethnography.
South African Journal of Education, 33,1-17. http://dx.doi.org/10.15700/saje. South African
v33n2a702

Tanjung, B.N. (2015). The effect of principal leadership, compensation and work motivation on teacher professionalism at private high schools in Medan. Journa of Humanities and Social Science, 20, 53-57.

Taylor, N., Mabogoane, T., \& Akoobhai, B. (2011). Service delivery report office of the presidency: The school sector. Johannesburg, South Africa: JET Education Sector.

Thomas, M., Kohli, V., \& Choi, J. (2014). Correlates of job burnout among human services workers: Implications for workforce retention. Journal of Sociology and Social Welfare, 41, 69-90.

Tomic, W., \& Tomic, E.N. (2008). Existential fulfilment and burnout among principals and teachers. Journal of Beliefs \& Values, 29, 11-27. http://dx.doi.org/10.1080/ 13617670801928191

Trisno, B., \& Nurdianto, D. (2014). The key factors affecting internal quality education services in secondary vocational schools. In Conference proceedings of the $3 r$ d UPI International Conference on Technical and Vocational Education and Training, pp, 15-17, 13-14 November, Bandung, Indonesia, Curran Associates. Inc, Red Hook, NY: United States of America.

Van der Berg, S., Taylor, S., Gustafsson, M., Spaull, N., \& Armstrong, P. (2011). Improving education quality in South Africa. Report for National Planning Commission. Department of Economics, University of Stellenbosch, Stellenbosch, South Africa.

Van der Westhuizen, E., \& Wessels, J. (2011). South African human resource management for the public sector. (2nd edn.). Cape Town: Juta \& Company Ltd.

Whitehead, A., Ryba, K., \& O'Driscoll, M. (2000). Burnout among New Zealand primary school teachers. New Zealand Journal of Psychology, 29, 52-60.

World at Work Model. (2011). Total reward model. Washington, DC: World-wide Headquarters, World at Work. Retrieved April 13, 2014, from http://www. worldatwork.org/home/htlm/home/jsp2010 